\title{
Rare Nineteenth-Century \\ Latin American Periodicals
}

\author{
F R E D E R I K M. L A UR I T E N
}

In his book South America Rediscovered, Tom B. Jones has written that "At the beginning of the nineteenth century, the wide circulation of Humboldt's Travels provided convincing evidence for the international character of the interest in South America. . . Between 1815 and 1830 the production of travel books on southern South America attained a volume which was not equalled again until after 1850."1 Our forebears of the nineteenth century gained knowledge-and misconceptions-from these travel books. Popular as these observations were, they are the impressions of foreigners and seldom take the native point of view. Original works of Latin American writers seldom appeared in translation. Though these same writers were influenced by literary and intellectual developments in Europe and the United States, their works were virtually ignored above the Pyrenees.

When the twentieth-century investigator wishes to rediscover what contemporary Latin Americans thought, he has the periodical literature as an excellent primary source. Because of their immediate publicity, these periodicals reflect reactions and developments of current literary styles, political events, and social life better than the general travel books.

The University of Iowa Library is fortunate in possessing over seventy nineteenth-century periodical titles representing various countries of Latin America. In time they range from the earliest periods of

\footnotetext{
*The author wishes to thank the staff of the Special Collections Department and Mr. Frank Hanlin for their aid in this investigation. Besides several studies on Latin American literature in the nineteenth century, I have also relied upon the descriptive lists of the rare book dealer Mr. Maury Bromsen for numbers $10,11,12,16,25,39,42,45,47$, and 61 .

1 Tom B. Jones, South America Rediscovered (New York, 1968), pp. 3-4. This informative book is a synthesis of many of these travel accounts and contains an extensive bibliography.
} 
independence to the very end of the century. Some titles can be found only in this collection and others are in very few research libraries in the United States.

The following is a bibliography of the nineteenth-century periodicals from Latin America in the Special Collections Department of The University of Iowa Library. The list is arranged by country and within each country by chronological order. For each entry the title is given first, followed by the city in which it was published. Volumes and/or numbers are given next and finally the dates. Only the Library's holdings are listed, and unless noted each title is the complete run. A brief description of each magazine is given with the intention of indicating its contents.

\section{MEXICO}

Mexico, with thirty-two titles, has the largest representation of periodicals in the Library. As is to be expected, almost all were issued in Mexico City, the metropolis and cultural capital. The journals represent a great variety of cultural life and reflect the wide interests both of the editors and the intended audience.

1. EL OBSERVADOR DE LA REPÚBLICA MEXICANA. Mexico City. v.1-3; June 6, 1827-January 2, 1828.

This weekly was published for a period immediately after the overthrow of Augustín Iturbide. Many of the articles deal with politics, natural history, and literature, but its most important function was to provide official news, which was barely available to the reading public in any other form. The Library lacks the second series, v.1-3, published in 1830.

2. GAZETA TAMPICO. Tampico.

The Library possesses only a supplement to number 15 , dated 17 March, 1832, of this exceedingly scarce journal. The issue was probably saved because it contains a declaration for Santa Anna with a diatribe against General Moctezuma. Santa Anna was quite popular at Tampico, for it was here he repulsed the feeble Spanish attempt at reconquest in 1829.

3. REGISTRO TRIMESTRE. Mexico City. v.1-2, no. 1; 1832-33.

The subtitle translated reads, "Collection of memoirs of history, literature, sciences, and the arts by a society of literary persons." This is a magazine of high literary and scholastic quality whose lengthy essays reflect the new nation's interest in politics and government. Science is mainly natural history, showing the influence of religion on the study of science. In natural history one was not so apt to run afoul of religious or theological complications. It was published by Ignacio 
Cumplido, later a member of the Academy of Letrán. The society referred to in the subtitle was almost certainly the informal gathering of young writers who later became the Academy of Letran in 1836. ${ }^{2}$

4. EL INDICADOR DE LA FEDERACION MEJICANA. Mexico City. v.1-3; 1833-34.

The interest which most of the new countries had in government and education is shown in the long, discursive articles. The fourth and final volume is lacking.

5. LA SOMBRA DE MOCTHEUZOMA XOCOYOTZIN. Mexico City, no. 1-12 plus supplements $I$ and $2 ; 1834$.

An important journal edited by Carlos Maria de Bustamante in which he presents his philosophy and opinions on government and politics in Mexico and South America.

6. REVISTA MEXICANA. Mexico City. v.1, no.1; 1835.

This "Scientific and literary periodical" continues the Registro Trimestre. Its aim was to be nonpolitical but rather in "the progress of national culture ... and general instruction and education." It contains a wide variety of articles from natural history to literature, all of a fairly high quality. Apparently it did not succeed in its aim, as only five issues were ever published.

7. EL RECREO DE LAS FAMILIAS. Mexico City. v.1, no.1-22; 1837-38?

A general magazine of essays on geography, civil and natural history, fine arts, science, and variety. There are essays on Calderón, poetry by Lamertin, and many biographies (especially of literary figures), philosophical discussions on the passions of love, as well as articles on the theatre and medical marvels.

8. EL MOSAICO MEXICANO. Mexico City. v.1-7; 1837-42.

"A collection of curious and instructive pleasantries." The scope is much the same as the previous title but with more interest shown in Mexico.

9. ALMACEN UNIVERSAL. Mexico City. v.1-2; 1840.

A magazine which combines the features of Reader's Digest with an almanac. It includes some translations from French and English periodicals. ${ }^{3}$ The articles cover a wide variety of subjects including history, geography, travel and literature.

2 Carlos González Peña, History of Mexican Literature, 3d ed. (Dallas, 1968), pp. $197-200$.

${ }^{3}$ In their eagerness to reject Spanish influence in literary styles and inspiration, the writers of the newly independent nations turned to other countries, especially France, for their instruction. The originality of Latin American writers is to be found in their content rather than style. See Alfred Coester, The Literary History of Spanish America (New York, 1941), p. ix 
10. EL APUNTADOR. Mexico City. v.1, no.1-24; 1841.

A rare title held by only a few libraries in the United States. It represented one of the earliest attempts in Mexico to produce a journal entirely devoted to the theatre and fine arts. Almost all the major writers, poets, and essayists of the day contributed to it. Contributors included members of the important literary society, the Academy of Letrán. 4

11. EL MUSEO MEXICANO. Mexico City. v.1-4, series 2, v.1; 184345.

A very rare journal which probably superseded El Mosaico Mexicano. The approach was scholarly and outstanding in its biographies, history, and literature. The emphasis was on the natural history and description of Mexico. The cartoons were pointed and at times virulent. The war with the United States caused it to cease.

12. EL LICEO MEXICANO. Mexico City. v.1-2; 1844.

Before becoming a fatality of the Mexican-American War, it established itself as a major literary journal. Many notable Mexican literary figures and historical writers helped to raise its quality above other journals of the age. It contained important contributions in poetry, biography, literary criticism, history, and prose emphasizing Mexican history.

13. EL ALBUM MEXICANO. Mexico City. v.1-2; 1849.

The beautiful hand-colored prints, flores animadas, contained in the two volumes are worth special notice. Otherwise this is another example of a collection of short articles on a variety of subjects ranging from the mineral production in Chihuahua to banking. Its purpose was to entertain and inform.

14. VARIEDADES DE LA CIVILIZACION. Mexico City. new series, v.l; 1852 .

As the title indicates, we again have a general magazine covering a variety of subjects, though perhaps of more than usual importance. Many of the articles include discourses given at the Academy of Letrán and the Hidalgo Lyceum by Don Francesco Granado Maldonado. The Academy of Letrán was especially important in the Mexicanization of literature and freeing it from foreign influences. Many periodicals of the time received contributions from members of the academy. ${ }^{5}$

15. BIBLIOTECA MEXICANA, POPULAR Y ECONOMICA. Mexico City. v.1-2; 1851-52.

Another general-popular periodical. The essays are longer than in

4 See n.2 above.

5 Peña, History of Mexican Literature, pp. 197-200, 263-264.

[6] 
most other periodicals of the type but cover the same areas. The scope and contents can be summed up in the subtitle, "Religious, political, historical, literary, scientific, artistic, industrial, agricultural, economic, dramatic, bibliographic, judicial [and] medical review of fine arts, useful knowledge, travel, discovery, customs, biographies, music, dance, gardening, instruction, recreation, etc." Little more need be said.

16. LA CAMELIA. Mexico City. v.1; 1853.

Essentially a woman's magazine dedicated to literature, theatre, and fashion. Within its pages are included some beautiful lithographs of Decaen together with essays, poetry, short novels, and biographies. A very rare periodical.

17. EL ARTISTA. Mexico City. v.1-2; 1853-54.

This serial probably supersedes El Album (no.13) which it resembles closely. It displays a greater interest in religion and the natural history of Mexico than El Album.

18. LA ILUSTRACION MEXICANA. Mexico City. v.1-5; 1851-55.

Its avowed aim was to "Satisfy the moral necessities of society" with a variety of articles and essays ranging from biography to natural history to literature.

19. ANALES MEXICANOS DE CIENCIAS, LITERATURA, MINERIA, AGRICULTURA, ARTES INDUSTRIA Y COMERCIO EN LA REPUBLICA MEXICANA. Mexico City. v.1, no.1-4; 1860.

The Scientific American of 1860 Mexico. The long illustrated articles emphasized minerals and diverse topics of natural history. The stress was on Mexico.

20. LA GUIRNALDA. Mérida [Yucatán]. v.1; 1860/61.

A "Society of Youths" published this literary organ under the direction of distinguished Yucatán literary artists. It has a religious orientation and shows a high degree of traditional education in the classics. Though very rare, it is only of ephemeral importance but does show aspects of provincial Mexican intellectual life.

21. ESPIRITU PUBLICO. Mexico City. v.1, no.1-26; 1865.

A daily journal "committed to defending the truest interests of the people." The importance of this periodical is that it was published during the era of Maximillian. The editors decried the political infighting which had gone on before and now praise the progress which is to come. They claim they will even criticize the government of the August Emperor. They spoke for the conservative class and as such were dedicated to defending the social interests favorable to the régime. 
22. LA ILUSTRACION POTOSIANA. San Luis Potosí. v.1; 1869/70. A "Weekly of literature, novelettes, notices, discoveries, variety, fashion, and advice." A general journal of a popular nature from the mineral-rich area outside of Mexico City, showing some of the literary interests and development in this province.

23. LA VOZ DE MORELOS. Mexico City. no.1-26; May-Oct. 1873.

"A periodical committed to sustain the candidacy of General Pedro Baranda for governor of the state [of Morelos]." This magazine should be compared with El Acusador (see below) since they both deal with the same election, which was one of the bitterest the region experienced in the nineteenth century. $L a$ Voz was edited by Alvaro Guzman and was motivated by a specific political purpose in electing a governor. It ceased with the election.

24. EL ACUSADOR. Mexico City. v.1, no.1-18; June 20-September $7,1873$.

An antigovernment "Periodical committed exclusively to combat the re-election of Leyva in the State of Morelos," edited by Cayetano M. Hernandez. In tone it was perhaps more provocative than acid or vituperative. Though our Library lacks no. 2, enough remains of this journal and La Voz De Morelos to shed some interesting light on local politics in the period shortly preceding the dictatorship of Porfirio Díaz.

25. EL ARTISTA. Mexico City. v.1-3; 1874-June 1875.

"A monthly devoted to bellas artes, literature and science." A bucolic journal which begins, "Ave Graecial Oh Graecia, Salud patria de arte, de la belleza y de la poesia." Edited by Jorge Hameken y Méxia and Juan M. Villela, it was of a literary nature and included contributions from many important Mexican writers. Art was emphasized also, and the fine lithographs were an outstanding feature.

26. EL MENSAJERO CATOLICO. Mexico City. v.1-2; 1875-76.

A religious periodical published by the Sociedad Católica de Mexico. Supersedes the journal Sociedad Católico. It contains sections on doctrine, "Echoes from the Vatican," poems of a religious nature, documents, bibliography and science.

27. LA ALIANZA LITERARIA. Guadalajara. v.1; 1876.

"Literary and scientific organ of the Literary Alliance." Antonio Zaragoza (1855-1910), minor romantic poet, was a major contributor and the subject of several articles in the journal. ${ }^{6}$ The results of this local literary society were popular and diverse.

28. LA CRUZ. Puebla. v.1; 1879.

"A periodical for the family: religion, morals, sciences and fine

6 Coester, Literary History of Spanish America, p. 282. 
arts." An organ of the church and of conservative thought. Although it did not deal exclusively with religious topics, the tone was one of moral inspiration. An earlier work of the same title appeared in Mexico City in 1855 when the church and conservatives were under attack from the liberal elements. Without the earlier title available for comparison, it is difficult to say whether the later title was influenced by it in any way. Puebla was one of the oldest centers of culture and religion outside of Mexico City. The Library has only the first volume. 29. EL ALBUM DE LA MUJER. Mexico City. v.1; 1883.

Five volumes were published, but the first probably resembles the others closely. The magazine was devoted to the "beautiful sex," namely the Mexican woman who is "above all modest, virtuous, and not frivolous." Through poems, short stories, essays, etc., it sought to instruct in morals. Edited by Concepción Grimeno de Flaquer ( $D i$ rectora Proprietaria), it is a good example of an upper class woman's magazine.

30. EL TIEMPO (literary edition). Mexico City. v.1; 1883.

Information is lacking as to how many volumes of this title were issued, but we do know it is quite rare. When it began it contained much poetry and longer essays on a variety of topics which have religious overtones, e.g., a poem on the Sacred Heart of Jesus. The later volumes become more newsy and deal with current events.

31. REVISTA NACIONAL DE LETRAS Y CIENCIAS. Mexico City. v.1-3; 1889-90.

A semimonthly periodical whose aim was to be the voice of the intellectual culture of Mexico and publish material on spiritual activities, philosophy, history and related subjects. The editors claimed to be expressly nonpolitical, but supported the dictatorship. A good example of culture under Díaz.

32. EL HOGAR. Chihuahua, v.1; 1899.

The Library owns volume one of this title, which continued to be published until 1923. The subtitle proclaimed it to be "A publication designed for the family, whose aim will always be to know the needs of the family in order to satisfy them" and definitely "not a periodical of politics, nor scholarly, nor purely literary or scientific." The contents included everything from games and recipes to essays on natural history, making it one of the most varied of the general magazines.

\section{GUATEMALA}

33. GACETA DE GUATEMALA. Guatemala City. v.13; 1860.

The Special Collections Department possesses only one nineteenthcentury title from Middle America and only one volume of that. The piece at hand resembles a newspaper in format and is arranged like 
an almanac. It is newsy and contains notices of political events, news of the outside world, plus various official documents.

\section{CUBA}

\section{EL KALEIDOSCOPIO. Havana. v.1, no.1-12; 1859.}

The only Cuban periodical we have. Its purpose was "Instruction, morality and recreation." Its articles stressed patriotism, philosophy, and character building. Though it resembles other magazines previously described, it contains relatively little natural history by comparison.

\section{COLOMBIA}

35. EL ZANCUDO. Cali. v.1, no.1-10; 1857-60.

This is perhaps the only extant, complete collection of this most rare and curious title. A zancudo is a mosquito; the journal appears to be a combination gossip column and satire magazine. A great many names are mentioned.

36. REVISTA DE BOGOTA. Bogotá. v.1, no.1-10, 12; 1871-1872.

Subtitled "Literature, science, philosophy, history, travel, theatre, etc." it tried to emulate the style and standards set by the Edinburgh Review, Revue des Deux Mondes, and Revista de Madrid. The editors intended it to be a literary organ for Colombians and to leave politics to others. It contains minutes of learned societies together with reports on natural science (geology, calendars, agriculture). The most important features are the inclusion of colonial historical documents, biographies, poems, and short stories by leading Colombian writers.

37. EL PAPEL PERIODICO ILUSTRADO. Bogotá. v.1-5; 1881-98.

A magazine of "Fine arts and bibliographical literature, science, customs and history." This was the first elaborately-illustrated periodical printed in Colombia; many of the illustrations were done by A. Urdaneta. It contains short articles on a variety of subjects. The best essays are on Colombian history. Among the important contributors was Doña Soledad Acosta de Samper (1831-1913). ${ }^{7}$

38. REVISTA LITERARIA. Bogotá. v.1-5; 1890-94.

This monthly published by Isidoro Laverde Amaga included "Bibliography, history, travel, geography, statistics, criticism, poetry, variety, etc." as its intended topics. Definitely a popular, newsy journal, it had an inter-American tone and showed a great interest in the United States. Fairly popular in its day, it attracted many Colombian literary

7 Coester, Literary History of Spanish America, pp. 290 and 301. 
artists who contributed essays, novelettes of great originality, and poetry. A good source for Colombian literary culture.

\section{VENEZUELA}

39. VENEZUELA. GACETA DEL GOBIERNO. Caracas. no.1-108; 1827-28.

The official gazette of the country, published each Wednesday and Saturday. It contained announcements and notices, news of the government and official proceedings. Besides including statistics of various sorts, it also contained news and communications from other South American governments, Great Britain, and the United States. The emphasis was on Venezuela and the treaties important to it. It was divided into official and nonofficial correspondence and included patent and trademark notices. Only the Library of Congress and Yale University report similar complete collections. Of outstanding importance for the early history of Venezuela.

40. BOLETIN DEL TOCUYO. Valencia. v.1-2 (no.1-8); 1840.

Like many of the post-revolution magazines, it reflects a strong interest in education and politics, all in a patriotic tone. Interesting because it brings attention to various laws passed by the government and comments on them. At least two spurious numbers (4 and 8) were printed by political rivals-much to the indignation of the editors. It was superseded by the Boletin Provincial de Barquisimeto. 41. EL CENTINELA DE LA PATRIA. Caracas. no.1-32; 1846-1847.

Each issue begins with the slogan "Leyes y patria y libertad proclaman. $Y$ oro, sangre, poder . . esas sus leyes, Esa libertad de que se llama inclitos vengadores." A political periodical whose aim was to sustain constitutional order and produce propaganda for the party of Paez-Monagas.

42. REVISTA LITERARIA. Caracas. no.1-19, 22-35; 1865.

The earliest journal of Venezuela and all South America to be devoted exclusively to literature. It is exceedingly rare and appealed to a very limited public. Many of the greater and lesser literary lights of Venezuela and Colombia were its contributors. The essays are inclined to be patriotic and the biographies of revolutionary figures were quite popular.

\section{ECUADOR}

43. LA VERDAD DESNUDA. Guayaquil. v.1-2; 1839-1840.

"The truth uncovered" was an outlet for contemporary political passions during the last days of the caudillo, General Juan José Flores. The tone is one of patriotism with an emphasis on Ecuador, though a lively interest is shown in the other nations of South America. The 
Treaty of Huancayo (between Ecuador and Peru) receives a great deal of attention.

44. EL PROGRESISTA. Quito. no.1-9; 1847.

There is no record as to whether more issues of this weekly were ever printed. The tenor is strongly anti-General Flores, who had just tried to regain control of the government which he lost in 1845 after fifteen years as caudillo. It also published notices of the happenings of congress and the government and discusses them. Official correspondence is reprinted within its pages. The years $1845-1849$ were one of the few periods of liberal government in Ecuador.

\section{PERU}

45. PERU. GACETA DEL GOBIERNO. Lima. v.7-9; January 1825March 4, 1826.

This official organ resembles the previous title and the Gazeta del Gobierno of Venezuela. It is an important contemporary source because it was published while the liberators were still living. In some respects it reads like a collection of press releases and includes letters to and from the president in an official capacity and contains official news of other countries. The incomplete volumes in the Library's collection begin with an announcement of the great victory of Ayachucho under General Antonio de Sucre and provide, through official decrees and laws, a chronological account of the establishment of control by Simón Bolívar in newly-liberated Peru.

46. LA PRENSA PERUANA. Lima. no.1-111; January 29-December $30,1828$.

This magazine was unavailable for examination and therefore cannot be evaluated at this time. What information was available indicates it is a journal of politics and government.

47. REVISTA DE LIMA. Lima. new series, v.1. t.1-2; 1873.

If the preceding seven volumes of this title resemble the last two, then we have another literary-scientific, general and popular periodical. It includes quite a few translations, including one of Byron's Childe Harold. It stands above most others of the same genre in literary quality. A great deal of the last two volumes is devoted to correspondence between Sucre and Bolívar.

48. REVISTA PERUANA. Lima. v.1-4; 1879-1880.

Edited by Mariano Felipe Paz Soldan, every issue maintained high scholarly standards. A shortage of paper coupled with the heightened military tensions accompanying the War of the Pacific, plus a reduction in the relevance of intellectual writing, combined to cause the journal to fold with volume five. For Peru in the nineteenth century this is an unsurpassed historical source of lasting value. 
49. EL ATENEO DE LIMA. v.1-6; 1886-1888.

An important organ for Peruvian intellectual and literary writing. Divided into sections on science, geography, politics and fine arts, the magazine is especially good on Peruvian life.

\section{CHIILE}

Chile is represented by thirteen periodicals published throughout the nineteenth century. In our collection it is surpassed numerically only by Mexico. Chile was perhaps the most liberal country in South America during this period. Certainly she suffered less from political turmoil and tyranny than her neighbors. She could afford and did have an active political and intellectual life with a great deal of freedom of the press. One of the earliest periodicals, El Hambriento, or The Starveling, contained satire and scathing articles against the liberals by Diego Portales, the unproclaimed autocrat. ${ }^{8}$ The intellectual life of the formative period of national letters was under the tutelage of Andres Bello. His contributions to education, law, and culture had great influence on his students who later became the political and cultural leaders of the country. Bello edited the government organ $E l$ Araucano for more than twenty years. His students later founded a periodical called El Semanario Literario to defend Bello and promote his ideas. ${ }^{9}$

50. EL MERCURIO CHILENO. Santiago. no.1-16; 1828-1829.

This magazine, although short-lived, was important in its day and has great historical interest. Edited by José Joaquín de Mora, a Spaniard who spent some years in Chile, it was an outlet for Mora's literary activity and thought as well as for other liberal intellectuals. One of Mora's fields of concern was education. He established a school, but his greatest monument is this journal. The government supported the magazine by ordering 250 subscriptions, thereby freeing Mora from many financial worries. He printed numerous literary and scientific articles, some poetry and foreign notices of importance. As a staunch liberal he defended what were then considered very progressive theories. He was asked by the liberal government of Joaquín Pinto to edit what is now called the Constitution of 1828. Much of Mora's work on the constitution was published in the Mercurio, and for this reason, if for no other, it ranks as one of the principal periodicals of the early years. The Italian naturalist Carlo Bertero published a catalogue of

8 John A. Crow, The Epic of Latin America (Garden City, N.Y., 1946), p. 639 and Coester, Literary History of Spanish America, pp. 196-197.

9 Coester, Literary History of Spanish Amcrica, p. 199. 
plants observed by him in Chile. This catalogue later served as a basis for future studies. ${ }^{10}$

51. EL MUSEO DE AMBAS AMERICAS. Valparaiso. v.1-3; 1842.

The contents of this magazine remind one of today's Nation. It had a political-philosophical tone in discussions of society and of education. An historical orientation made for small circulation. The descriptions of various Chilean cities are of interest.

52. EL SEMANARIO DE LAS FAMILIAS. Valparaiso. v.1; 1847/48.

A typical general, popular periodical of the nineteenth century with articles on a variety of topics. It includes a number of essays translated from French and English sources. The editor intended it to be a "Collection of instructive articles and pleasant literature."

53. REVISTA DE SANTIAGO. Santiago. v.1-3; 1848-1849.

The total number of volumes published was seven, each with the subtitle, "The latest results of science, literature, and the arts." Each issue began with world affairs followed by national news, a bibliography of Chile during the past month, then longer essays. Prescott's Conquest of Peru appeared in serialized form in each issue. The essays were given over to economics and politics with a fair degree of social consciousness. It was edited by J. V. Lastarria, who published many of the contemporary literary figures, including Eusebio Lillo (1826-1910), liberal and poet, who also helped found the journal.11

54. CORREO LITERARIO. Santiago. v.1, no.1-22; 1858.

The Library's set is incomplete and lacks the second series numbers 1-28. It contains plays, theatre reviews, political commentary, poetry, and short stories by Chilean writers, besides cartoons on contemporary life and events. It claimed to be the first illustrated periodical in the area.

55. REVISTA DEL PACIFICO. Valparaiso. v.1-5; 1858-1861.

The most important contributor was Guillermo Blast Gana, who wrote an original novel which appeared in serialized form. Blast Gana was one of Chile's most important writers during the nineteenth century, and he encouraged many minor poets of the day. ${ }^{12}$ At its start the magazine included material presented at the Sociedad de Amigos de la Ilustración. Other subjects included longer articles of a descriptive-historical nature as well as literature and poetry.

56. REVISTA DE SUD-AMERICA. Valparaiso. v.1-4, no.9; 1860-63.

10 Raul Silva Castro, Prensa y Periodismo en Chile (Santiago, 1958), pp. 95-97 and Coester, Literary History of Spanish America, p. 196.

11 Coester, Literary History of Spanish America, p. 210.

12 Silva Castro, Prensa, pp. 231-35 and Coester, Literary History of Spanish America, p. 212. 
Published by the Sociedad de Amigos de la Ilustración; there were close connections with the Revista Del Pacifico (no.55). The Library wants only volume 4 , number 10 , to have a complete run. There is a greater emphasis on the historical than the literary, with Chile receiving most attention. Besides long scholarly articles and critical essays, theatre reviews were included.

57. EL CORREO DEL DOMINGO. Santiago. no.1-26; April 20-October 12, 1862.

This short-lived periodical was a "Review of politics, literature and notices." Included were articles on topics such as the Anglo-French in Uruguay and the monarchy in America before Spain. All of Latin America received attention in general articles of a popular nature.

58. EL CONDOR. Santiago. v.1, no.1-6; June 15-July 19, 1863.

Another journal with a short life. The final issues 7 and 8 are lacking from this set. It was a periodical of politics and illustrates Chilean frankness on internal affairs. It contains some interesting contemporary comments on Maximillian's occupation of Mexico.

59. EL SAN MARTIN. Valparaiso. v.1-3 (no.1-180); 1864-1866.

Edited by Antonio Monticelli, Luís Díaz, N. Manterola and the brilliant journalist Santiago Godoy. This is one of the most interesting journals in the collection. The San Martin was instrumental in fanning the flames of patriotism against Spain with provocative articles and vituperative cartoons on the Spanish Queen Isabel II and her ministers. By 1865 events had progressed to the point of an alliance among Peru, Chile, Bolivia and Ecuador. The Spanish navy retaliated against an alleged insult by bombarding the port of Valparaiso during which the offices of the San Martin were heavily damaged. The war ended with a moral victory for Chile and resulted in the beginning of Chilean naval power. It was later said that the San Martin played a major rôle in inciting the conflict. ${ }^{13}$

60. REVISTA AMERICANA. Santiago. v.1, no.1-12; August-November, 1869.

An "Illustrated periodical of literature and science." During its brief existence the journal included literary essays, poetry, articles on theatre, and an original novel. Science consisted of a long article continuing through several issues on the value of mother's milk as viewed by a mother, the children, the family and society, complete with charts and tables.

61. LA LECTURA. Santiago. v.1-2; July 1883-June 1885.

A very rare literary periodical of which no other copies are known

13 Silva Castro, Prensa, pp. 272-273. 
to exist in the United States. Its intention was to be a "Family weekly of literature, sciences, arts, travel, useful knowledge, etc." After the War of the Pacific (1879-1883), it was the first periodical to be devoted largely to literature at a time when intellectuals of the country longed for an aesthetic expression of national values. Many outstanding Chilean writers contributed high quality essays, biographies, plays and poetry.

62. EL FIGARO. Santiago. no.1-82; 1890-1891.

This is the only complete run known outside of Chile. Principally a magazine of political satire and cartoons, especially against José Balmaceda (1840-1891), who immediately censored it on January 1, 1891, when the president assumed dictatorial powers in his struggle with the Congress.

\section{ARGENTINA}

63. EL PLATA CIENTIFICO Y LITERARIA. Buenos Aires. v.1-3, 5; 1854-1855.

A "Review of the State of Plata on legislation, jurisprudence, political-economy, natural science and literature" founded by Miguel Navarro Viola. It contained long discussions on the law and a novel by Vincente Fidel López (1815-1903), La Novia del Hereje, o la Inquisicion de Lima, which reconstructed Lima society circa 1578.14 The Library lacks volumes 4, 6 and 7 .

64. LA REVISTA DE BUENOS AIRES. Buenos Aires. v.1-24; 18631871.

"Historical Americana, literature and law to serve southern South America," edited by Vincente G. Quesada and Miguel Navarro Viola. As perhaps the most important cultural magazine of Argentina after 1860 it was essentially a vehicle of culture and investigation of the highest level, nonpartisan, liberal and noncontroversial. It is most representative of intellectual life during the period. ${ }^{15}$

65. EL MOSQUITO. Buenos Aires. v.9-12; 1871/72-1874.

A "periodico satírico y burlesco de caricaturas" which began in 1863. The editor was Gerente Enrique Stein. As the title and subtitle indicate, it was primarily a journal of satire and cartoons. As always, politicians and social customs were the prime targets.

66. REVISTA ARGENTINA. Buenos Aires. v.1-6; 1868-1869.

Altogether thirteen volumes were published. This was one of three literary journals which flourished during the administration of Bar-

14 Coester, Literary History of Spanish America, pp. 160-161.

15 Coester, Literary History of Spanish America, pp. 124, I61. 
tolome Mitre. ${ }^{16}$ One of the outstanding contributors was Luís L. Dominguez (1819-1898) whose historical articles later became part of his Historia Argentina. Education and history of Argentina received much attention in long scholarly articles.

67. REVISTA DE LA PLATA. La Plata. v.1; 1885/86.

No information is available as to whether other volumes were published. It resembles Harper's Weekly in format and contents. There are general, superficial, illustrated articles on a variety of topics with numerous descriptions of foreign places.

68. REVISTA NACIONAL. Buenos Aires. v.1-11, 13-15; 1886-1892.

A monthly periodical, largely devoted to history, which continued to be published until 1910. The volumes in the Library's collection were edited by Adolfo P. Carranza. Though the emphasis was on Argentine history, articles of a literary, scientific and bibliographical nature were included as well as some long poems.

69. REVISTA DEL PARAGUAY. Buenos Aires. v.1; 1891.

A magazine of "Science, literature and arts" which ran to a total of four volumes. "A monthly periodical designed to further the interests of the Republic of Paraguay." There is very little contemporary material in the first volume, which was devoted mainly to the historical past of Paraguay and written by non-Paraguayans to recreate the forgotten Paraguay.

\section{PARAGUAY}

70. EL PARAGUAYO INDEPENDIENTE. 2d edition. Asunción. v.1-2; 1859.

Originally published in 1845 (five years after the death of Dr. Francia), it is of value for Paraguayan views of the country when it was virtually unknown. It begins by discussing the history of Paraguay and the grievances against Argentina and how Paraguayan independence was achieved. There is a section entitled "official documents" which includes notices, treaties, laws, communication, etc.

71. LA ILUSTRACION PARAGUAYA. Asunción. no.1-20; 1869-1870.

Short articles on science, literature and fine arts, with a Paraguayan emphasis, as well as other articles of a general nature.

\section{URUGUAY}

72. EL TAPON. Montevideo. no.1-39, 42-43; 1875-1876.

Tapon means cork or stopper. A political magazine which dealt out satire with a vengeance upon all deserving government officials and corruption.

16 The three were La Revista Argentina, El Correo del Domingo, and La Revista de Buenos Aires. See Coester, Literary History of Spanish America, p. 120. 
73. REVISTA NACIONAL DE LITERATURA Y CIENCIAS SO-

CIALES. Montevideo. v.1-3 (no.1-60); 1895-1897.

A literary journal which welcomed modernist ideas of art, promoted by José Enrique Rodó (1872-1917). Rodó, an avowed modernista, was influenced by the views of Rubén Darío. The contributions show a literary expression of political and social awareness among the new generation of writers.

74. LA REVISTA. Montevideo. v.1-2; 1899-1900.

The closing years of the nineteenth century saw this significant outlet for Latin American writers. There were poems and short essays of literary interest and ability on a variety of subjects, including politics, psychology, and the military. A section on science was also included.

Seventy-four titles is but a fraction of the total number of periodicals published in Latin America during the nineteenth century. Almost every magazine in the list is of a general nature and meant for popular consumption. Most, but not all, contain creative literary efforts and will be of great interest and use to anyone investigating this aspect of the culture of the area or a specific nation during the period.

Several other possibilities for scholarship suggest themselves. Besides the literary aspect noted above, some titles provide documentation and background for historical research. There are titles which were official government organs or propaganda journals for political parties. A more complete study of La Voz de Morelos (no. 23) and El Acusador (no. 24) could provide interesting results. The Chilean journal El Mercurio Chileno (no. 50) contains the nucleus for several studies. The history of science in Latin America has yet to be investigated. Many titles in the list contain articles on various aspects of science during the nineteenth century. There are many other areas of investigation available to the researcher through these periodicals, as the preceding pages have tried to show. 


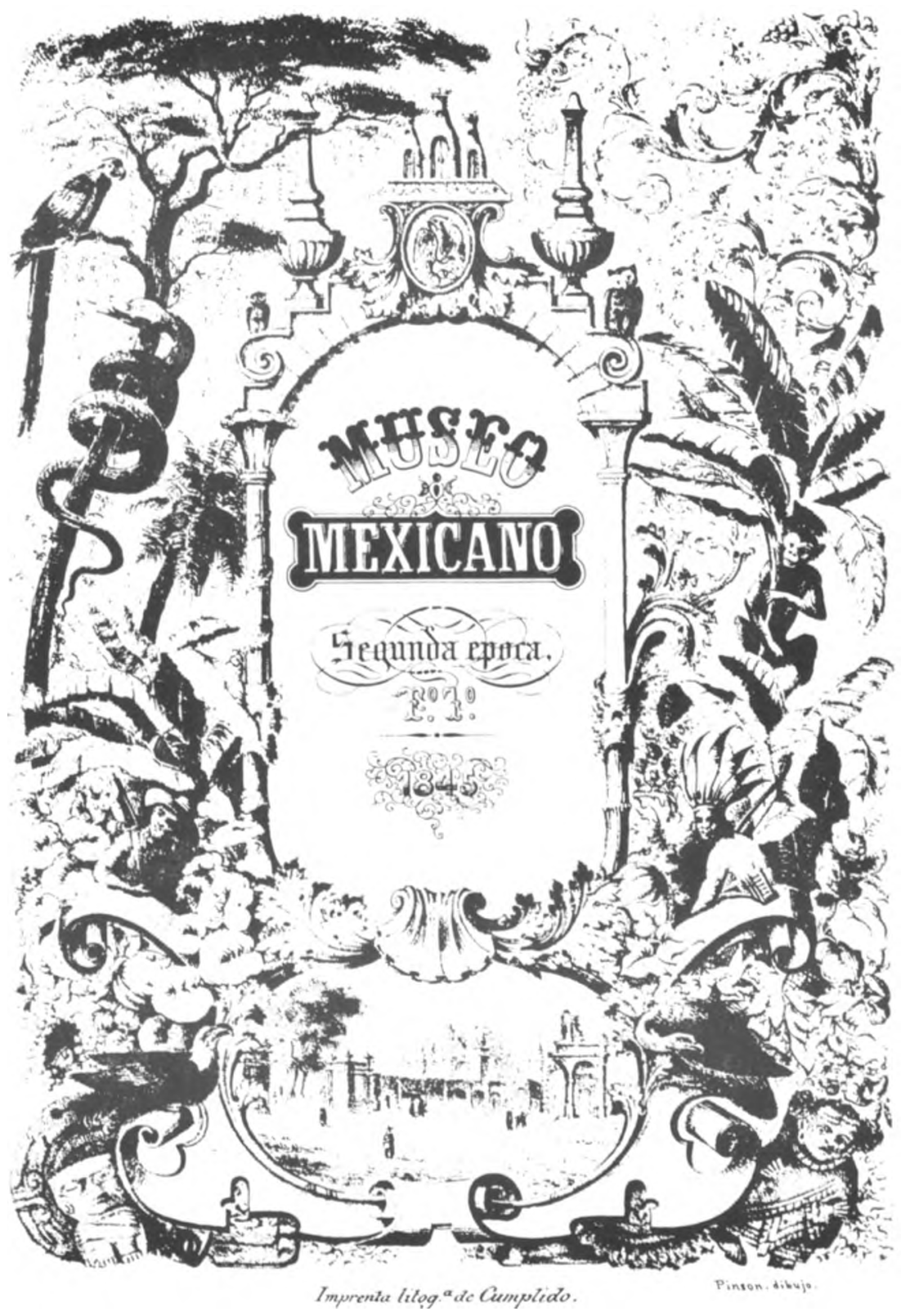

Illustrated title page to volume one, second series, of the perioclical Museo Mexicano published in Mexico Cits in 1845. Item eleven in the Lauritsen list. 


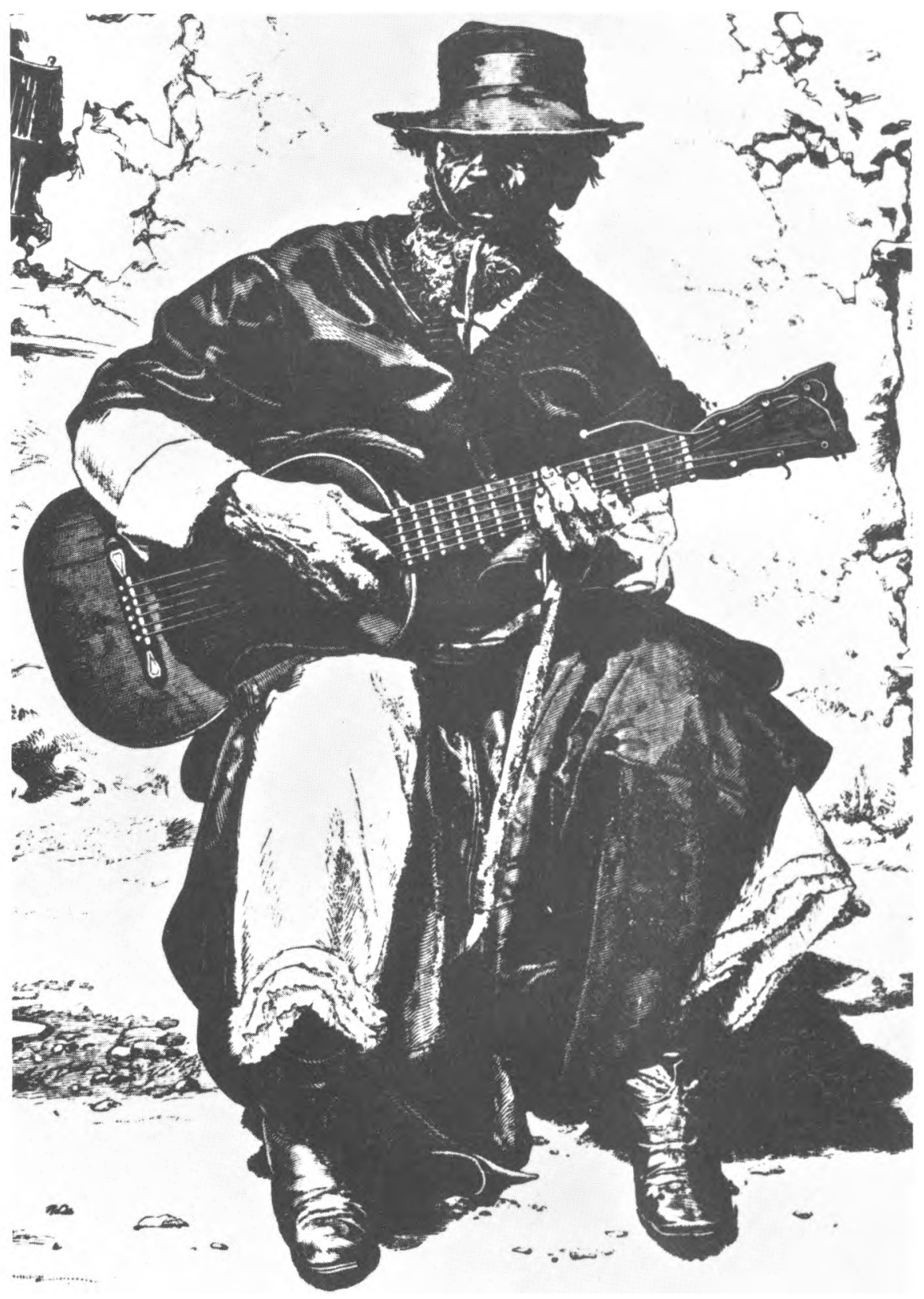

